\title{
MENINGKATKAN MOTIVASI DAN HASIL BELAJAR PESERTA DIDIK KELAS IV SEMESTER SATU TAHUN PELAJARAN 2017/2018 DENGAN ENGOPTIMALKAN PENERAPAN MODEL DISCOVERI LEARNING DI SD NEGERI 14 CAKRANEGARA
}

\author{
I Ketut Nirta \\ Guru Kelas IV SD Negeri 14 Cakranegara
}

\begin{abstract}
Abstrak. Penelitian ini bertujuan untuk mengetahui efektifitas penerapan pendekatan Saintifik model Discovery Learning dalam upaya meningkatkan motivasi dan hasil belajar Peserta didik Kelas IV SD Negeri 14 Cakranegara. Manfaat penelitian ini adalah mendorong peserta didik untuk mengembangkan ketrampilan belajar dalam kelompok (kognitif) dan bersosiolisasi dengan teman sebagai dalam proses pembelajaran di kelas senyatanya. Dan bagi guru meningkatkan pengembangan pendekatan dan model pembelajaran dengan penerapan saintifik Model discovery learning dalam pembelajaran kerja kelompok (kooperatif). Penelitian ini dilaksanakan dua siklus, masing-masing siklus kegiatannya adalah; perencanaan, pelaksanaan, observasi dan refleksi. Hasil akhir tindakan pada siklus II menunjukkan bahwa hasil observasi guru memperoleh skor rata-rata $(4,63)$ dan hasil observasi Peserta didik mencapai skor rata-rata $(4,37)$. Sedangkan hasil belajar Peserta didik mencapai nilai rata-rata $(89,61)$, artinya indicator keberhasilan $(\geq 4,0)$ dan hasil belajar $(\geq 75,00)$ telah terlampaui. Karena indikator keberhasilan telah terbukti penelitian dinyatakan berhasil dan dihentikan pada siklus II.
\end{abstract}

Kata Kunci : Motivasi dan hasil Belajar-Pendekatan Saintifik Model Discovery Learning.

\section{PENDAHULUAN}

Proses pembelajaran di SD Negeri 14 Cakranegara khususnya pada mata pelajaran Tematik yang berlaku selama ini masih cenderungnya mengarah pada guru yang aktif menjelaskan materi pelajaran dengan berapiapi tanpa memperdulikan kondisi peserta didiknya.Proses pembelajaran semacam ini telah melahirkan peserta didik yang pasif, kurang kreatif, kurang termotivasi dalam mengingat pelajaran Tematik sehingga prosentase keberhasilan pada peserta didik sangat memprihatinkan dan berdampak pada rendahnya tingkat kepercayaan peserta didik terhadap guru Tematik dalam proses pembelajaran di kelas senyatanya.

Kondisi nyata yang terjadi pada peserta didik kelas IV SD Negeri 14 Cakranegara adalah sebagai berikut: 1) peserta didik di kelas ini merupakan penyebaran dari sekolahsekolah yang kualitasnya rendah, 2) peserta didik yang memiliki nilai rata-rata UAS BN pas-pasan, 3) peserta didik yang pada saat proses pembelajaran kurang termotivasi dan cenderung bermain-main, saling lempar buku, keluar masuk kelas tanpa izin, 4) peserta didik yang motivasi belajarnya rendah dan pada saat diadakan ulangan harian memperoleh nilai rata-rata di bawah KKM. Kondisi sebagaimana tersebut diatas dialami pula pada proses pembelajaran mata pelajaran Tematik. Selama proses pembelajaran peserta didik cenderung tidak peduli terhadap apa yang disampaikan oleh guru mata pelajaran. Ketika guru meminta kepada peserta didik untuk bertanya terhadap materi pelajaran yang disajikan, jika ternyata belum faham, belum mengerti, atau tidak tahu sama sekali semuanya diam, ketika peserta didik di berikan tugas secara berkelompok hanya beberapa orang peserta didik saja yang aktif. Ketika masing-masing kelompok disuruh maju untuk mempresentasikan hasil kerja kelompoknya cenderung tidak bersedia bahkan masing-masing anggota kelompok saling tunjuk yang tidak ada hasilnya.

Faktor penyebab terjadinya situasi kelas yang sangat kurang kondusif dalam proses pembelajaran tersebut adalah berasal dari guru itu sendiri maupun berasal dari peserta didik. Selama ini guru Tematik mengajar cenderung mendominasi dengan gaya ceramah yang berapi-api tanpa memperdulikan kondisi peserta didik. Guru Tematik sekaligus sebagai peneliti sebenarnya sudah menerapkan pendekatan saintifik 
sebagaimana yang tertera pada Permen 81 A Tahun 2013 tentang kurikulum 2013, tetapi masih belum optimal dan belum sesuai dengan harapan. Sementara penyebab dari peserta adalah rendahnya kompetensi yang dimiliki serta kurang gairah dalam mengikuti pelajaran Tematik. Apapun yang ditugaskan oleh guru, peserta didik nampak cuek dan tidak peduli akan akibat yang akan terjadi pada dirinya.

Banyak solusi yang bisa dilakukan oleh peneliti, tetapi yang dianggap mampu meningkatkan motivasi dan hasil belajar peserta didik kelas IV mata pelajaran Tematik yaitu dengan mengoptimalkan pendekatan "saintifik" dengan menggunakan Model discovery learning. Pendekatan saintifik ini memiliki keunggulan bila di bandingkan dengan pendekatan yang lain karena proses pembelajaran terdiri atas lima pengalaman belajar pokok yaitu; a) mengamati, b) menanya, c) mengumpulkan informasi, d) mengasosiasi, dan e) mengkomunikasikan. Dalam pengembangan kegiatan pembelajar dengan pendekatan saintifik ini dirancang sebagai berikut; 1) kegiatan pembelajaran disusun untuk dapat melaksanakan proses pembelajaran secara professional, 2) kegiatan pembelajaran memuat rangkaian kegiatan manajerial yang dilakukan guru agar peserta didik dapat melakukan kegiatan seperti di silabus, 3) kegiatan pembelajaran untuk setiap pertemuan merupakan scenario/langkahlangkah guru agar peserta didik aktif belajar. Kegiatan ini diorganisasikan menjadi kegiatan: pendahuluan, inti dan penutup.

Untuk membuktikan bahwa pendekatan saintifik strategi discovery learning dengan model diskusi dapat meningkatkan motivasi dan hasil belajar peserta didik kelas IV Semester Satu tahun pelajaran 2018/2019 maka dipandang perlu untuk mengadakan penelitian tindakan kelas (PTK) dengan judul "Meningkatkan Motivasi dan hasil belajar Peserta Didik kelas IV Semester Satu tahun pelajaran 2018/2019 dengan mengoptimalkan penerapan Model discovery learning di SD Negeri 14 Cakranegara".

\section{Rumusan Masalah}

Apakah dengan mengoptimalkan penerapan model Discovery Learning dapat meningkatkan motivasi dan hasil belajar
Tematik peserta didik kelas IV Semester Satu tahun pelajaran 2018/2019 di SD Negeri 14 Cakranegara?

\section{Tujuan Penelitian}

untuk mengetahui efektifitas penerapatan model Discovery Learning dalam upaya peningkatan motivasi dan hasil belajar Tematik peserta didik kelas IV Semester Satu tahun pelajaran 2018/2019 di SD Negeri 14 Cakranegara.

\section{Manfaat Penelitian * Bagi Peserta Didik}

1. Mendorong peserta didik untuk mengembangkan ketrampilan belajar dalam kelompok (kognitif) dan bersosiolisasi dengan teman sebagai dalam proses pembelajaran di kelas senyatanya.

2. Motivasi belajar Tematik bagi peserta didik dalam upaya pemahaman secara mandiri (eksplorasi) terhadap mata pelajaran Tematik sehingga hasil belajar dapat ditingkatkan.

\section{* Bagi Guru}

1. Meningkatkan pengembangan pendekatan dan model pembelajaran dengan penerapan model discovery learning dalam pembelajaran kerja kelompok (kooperatif).

2. Menumbuhkan aspirasi secara ilmiah dalam menjalankan profesi keguruan terutama dalam pengembangan keprofesian berkelanjutan (PKB) bagi guru Tematik.

\section{KAJIAN PUSTAKA \\ Motivasi}

Motivasi berasal dari bahasa latin Movere yang berarti dorongan atau daya penggerak. Motivasi adalah daya penggerak yang menciptakan rangsangan belajar seseorang, agar mereka aktif belajar secara efektif dan terintegrasi dengan segala usaha mencapai hasil belajar yang memuaskan.

Menurut Mc. Donald C (dalam Nurhayati: 2006) bahwa motivation is a energy change within the person characterizet by affective arraousal and anticipatory goal reactions. Motivasi adalah suatu perubahan energy di dalam pribadi seseorang yang ditandai dengan timbulnya efektif (perasaan) dan reaksi untuk mencapai tujuan. Peserta didik yang memiliki motivasi yang kuat akan 
mempunyai banyak energy untuk melakukan kegiatan belajar. Hasil belajar akan optimal kalau ada motivasi. Semakin tepat motivasi yang diberikan maka akan semakin belajar pula pelajaran itu.

David Mc. Clelland (dalam Nurhayati: 2006) mengemukakan bahwa motivasi adalah kekuatan yang mendorong orang untuk melakukan sesuatu termasuk belajar yang dipengaruhi oleh kebutuhan-kebutuhan, antara lain kebutuhan prestasi yaitu hasrat untuk melakukan sesuatu yang lebih baik atau efisien dalam memecahkan masalah atau menguasai latihan yang sulit.,

Menurut Hoy dan Miskel (dalam Nurhayati: 2006) motivation is defined as the complex of force, drives, needs, tension states, or orther internal psychological mechanism that star an maintain activity toward the achievement of personal goals. Dengan demikian motivasi dapat mempengaruhi prilaku seseorang dalam melakukan sesuatu, mempertahankan kegiatan yang telah ditetapkan terutama hasil belajar peserta didik.

Meskipun para ahli mendefinisikan dengan cara lain gaya yang berbeda, namun esensinya menuju kepada maksud yang sama, ialah bahwa motivasi itu merupakan:

1. Suatu kekuatan (power) atau tenaga (forces) atau daya (energy); atau

2. suatu keadaan yang kompleks (a complex state) dan kesiapsediaan (preparatory set) dalam diri individu (organism) untuk bergerak (to move, motion, motive) kearah tuntutan tertentu, baik disadari maupun tidak disadari.

Motivasi tersebut timbul dan tumbuh berkembang dengan jalan;

(1) Datang dari dalam diri individu itu sendiri (instrinsik); dan

(2) Datang dari lingkungan (ektrinsik)

(Syamsuddin Makmun, 2005: 37)

Berdasarkan konsep motivasi dari beberapa teori di atas, maka motivasi belajar dirumuskan sebagai kecenderungan peserta didik mengembangkan diri, dengan melakukan kegiatan belajar yang didukung oleh hasrat yang kuat untuk mencapai prestasi sebaik mungkin. Dan harus memperhatikan indicator motivasi sebagai berikut: 1) harapan sukses, 2) kerja keras, 3) tanggung jawab dan disiplin, 4) kemandirian dalam bertindak, 5) berani mengambil resiko, dan, 6) berusaha mencari cara-cara baru dalam memecahkan masalah sehingga akan meningkatkan keefektifitasan kondisi belajar.

Dalam kegiatan belajar mengajar, apabila ada seorang peserta didik, misalnya tidak berbuat sesuatu yang seharusnya dikerjakan, maka perlu diselidiki sebab-sebabnya. Sebabsebab itu biasanya bermacam-macam, mungkin iya tidak senang, mungkin sakit, lapar, ada problem pribadi dan lain-lain. Hal ini berarti pada diri anak tidak terjadi perubahan energy, tidak terangsang efeksinya untuk melakukan sesuatu, karena tidak memiliki tujuan atau kebutuhan belajar. Keadaan semacam ini perlu dilakukan daya upaya yang dapat menemukan sebab musababnya dan kemudian mendorong seorang peserta didik itu mau melakukan pekerjaan yang seharusnya dilakukan, yakni belajar. Dengan kata lain peserta didik itu perlu diberikan rangsangan agar tumbuh motivasi pada dirinya. Atau singkatnya perlu diberikan motivasi. (Sudirman:1996:74-75)

\section{Hasil belajar}

Mukhtar (2003:54) mengatakan bahwa pengertian hasil belajar tidak dapat dipisahkan dan apa yang terjadi dalam aktifitas pembelajaran baik di kelas maupun diluar kelas. Apa yang dialami oleh peserta didik dalam proses pengembangan kemampuannya merupakan apa yang diperoleh dalam belajar dan pengalaman tersebut pada akhirnya dipengaruhi oleh beberapa faktor diantaranya keadaan kognitif, afektif dan psikomotornya pada waktu belajar. Kualitas pengajaran yang diterimanya dan cara pengelolaan proses interaksi yang dilakukan oleh guru.

Masalah evaluasi hasil belajar meliputi alat ukur yang digunakan, cara menggunakan, cara penilaian dan evaluasinya (Harus Rasid dan Mansur, 2008: 9). Evaluasi hasil belajar yang berhubungan dengan tugas guru rutin dilakukan evaluasi hasil, yang juga dijadikan umpan balik, evaluasi hasil bertujuan menilai apakah hasil belajar dicapai sesuai dengan tujuan (Lukmanul Hakim, 2008:165).

Pakar pendidikan lain mendefinisikan bahwa yang dimaksud hasil belajar adalah perubahan perilaku secara keseluruhan bukan salah satu aspek potensi kemanusiaan saja 
(Supriyono, 2009:19). Berbeda dengan pendapatnya Bloom (Dalam Sumiati danAska, 2008). Hasil belajar mencakup kemampuan kognitif, afektif, dan psikomotorik. Jadi pendapat ini mengisyaratkan bahwa haasil belajar peserta didik harus diukur dengan tes tertulis, tes sikap, dan kemampuan skil secara nyata selama proses pembelajaran di kelas senyatanya.

Dalam penelitian ini yang dimaksud dengan hasil belajar adalah tes ulangan harian yang dilaksanakan secara tertulis pada akhir pembelajaran dan nilai hasil diskusi kelompok yang dinilai secara perorangan.

\subsubsection{Pendekatan}

Pendekatan dalam pembelajaran adalah peserta didik/peserta yang aktif. Titik tolak pemikiran bahwa peserta didik diajar dan guru mengajar beralih kepandangan bahwa peserta didik belajar, peserta didik mempelajari beberapa hal yang terus menerus dalam perjalanan hidupnya (Sumiati dan Aska, 2008:8). Dalam praktiknya pendekatan ini selalu disandingkan dengan pembelajaran yang konstektual. Dengan pembelajaran ini peserta didik akan memperoleh pengalaman belajar yang mengesankan dan akan diabadikan dalam kehidupan sebagai sosok yang demokratis, berfikir kreatif, yang selalu mengedapkan nilai-nilai kekeluargaan dan kegotongroyongan.

Pembelajaran dengan pendekatan saintifik adalah pembelajaran yang terdiri atas kegiatan mengamati (untuk mengidentifikasi hal-hal yang ingin diketahui), merumuskan pertanyaan (dan merumuskan hipotesis), mencoba/mengumpulkan data (informasi) dengan berbagai teknik, mengasosiasi/ menganalisis/mengolah data (informasi) dan menarik kesimpulan serta mengkomunikasikan hasil yang terdiri dari kesimpulan untuk memperoleh pengetahuan, keterampilan dan sikap. Langkah-langkah tersebut dapat dilanjutkan dengan kegiatan mencipta.

Kurikulum 2013 mengembangkan sikap spiritual, sikap sosial, pengetahuan, dan keterampilan peserta didik. (Permendikbud Nomor 54/2013) Bagaimana Kurikulum 2013 memfasilitasi peserta didik memperoleh nilainilai, pengetahuan, dan keterampilan secara berimbang?, bagaimana proses pembelajaran dilaksanakan?

Berikut contoh kegiatan belajar dan deskripsi langkah-langkah pendekatan saintifik pada pembelajaran kurikulum 2013 adalah:

1. Mengamati: membaca, mendengar, menyimak, melihat (tanpa atau dengan alat) untuk mengidentifikasi hal-hal yang ingin diketahui - Mengamati dengan indra (membaca, mendengar, menyimak, melihat, menonton, dan sebagainya) dengan atau tanpa alat.

2. Menanya: mengajukan pertanyaan tentang hal-hal yang tidak dipahami dari apa yang diamati atau pertanyaan untuk mendapatkan informasi tambahan tentang apa yang diamati - Membuat dan mengajukan pertanyaan, tanya jawab, berdiskusi tentang informasi yang belum dipahami, informasi tambahan yang ingin diketahui, atau sebagai klarifikasi.

3. Mencoba/mengumpulkan data (informasi): melakukan eksperimen, membaca sumber lain dan buku teks, mengamati objek/kejadian/aktivitas, wawancara dengan narasumber Mengeksplorasi, mencoba, berdiskusi, mendemonstrasikan, meniru bentuk/gerak, melakukan eksperimen, membaca sumber lain selain buku teks, mengumpulkan data dari nara sumber melalui angket, wawancara, dan memodifikasi/ menambahi/mengembangkan.

4. Mengasosiasikan/mengolah informasi: Peserta Didik mengolah informasi yang sudah dikumpulkan baik terbatas dari hasil kegiatan mengumpulkan/eksperimen mau pun hasil dari kegiatan mengamati dan kegiatan mengumpulkan informasi mengolah informasi yang sudah dikumpulkan, menganalisis data dalam bentuk membuat kategori, mengasosiasi atau menghubungkan fenomena/informasi yang terkait dalam rangka menemukan suatu pola, dan menyimpulkan.

5. Mengkomunikasikan: Peserta Didik menyampaikan hasil pengamatan, kesimpulan berdasarkan hasil analisis 
secara lisan, tertulis, atau media lainnya menyajikan laporan dalam bentuk bagan, diagram, atau grafik; menyusun laporan tertulis; dan menyajikan laporan meliputi proses, hasil, dan kesimpulan secara lisan.

6. Dapat dilanjutkan dengan Mencipta: Peserta Didik Menginovasi, mencipta, mendisain model, rancangan, produk (karya) berdasarkan pengetahuan yang dipelajari.

\section{Model Discovery Learning}

Model discovery learning adalah teori belajar yang didefinisikan sebagai proses pembelajaran yang terjadi bila pelajar tidak disajikan dengan pelajaran dalam bentuk finalnya, tetapi diharapkan mengorganisasi sendiri. Discovery terjadi bila individu terlibat, terutama dalam penggunaan proses mentalnya untuk menemukan beberapa konsep dan prinsip. Discovery dilakukan melalui observasi, klasifikasi, pengukuran, prediksi, penentuan dan inferi. Discovery learning merupakan pembentukan kategorikategori atau konsep-konsep, yang dapat memungkinkan terjadinya generalisasi.

Peserta didik dikatakan memahami suatu konsep apabila mengetahui lima unsur dari konsep itu, meliputi: 1) Nama; 2) Contohcontoh baik yang positif maupun yang negatif; 3) Karakteristik, baik yang pokok maupun tidak; 4) Rentangan karakteristik; 5) Kaidah

\section{- Kelebihan Penerapan Discovery Learning}

1. Membantu peserta didik untuk memperbaiki dan meningkatkan keterampilan-keterampilan dan prosesproses kognitif.

2. Pengetahuan yang diperoleh melalui model ini sangat pribadi dan ampuh karena menguatkan pengertian, ingatan dan transfer.

3. Menimbulkan rasa senang pada peserta didik, karena tumbuhnya rasa menyelidiki dan berhasil.

4. Model ini memungkinkan peserta didik berkembang dengan cepat dan sesuai dengan kecepatannya sendiri.

5. Peserta didik mengarahkan kegiatan belajarnya sendiri dengan melibatkan akal dan motivasinya.
6. Strategi ini dapat membantu peserta didik memperkuat konsep dirinya, karena memperoleh kepercayaan bekerja sama dengan yang lainnya.

7. Berpusat pada peserta didik dan guru yang bersama berperan aktif mengeluarkan gagasan-gagasan.

8. Membantu peserta didik menghilangkan skeptisme (keragu-raguan) karena mengarah pada kebenaran yang final dan tertentu atau pasti.

9. Peserta didik akan mengerti konsep dasar dan ide-ide lebih baik;

10. Membantu dan mengembangkan ingatan dan transfer kepada situasi proses belajar yang baru;

11. Mendorong peserta didik berfikir dan bekerja atas inisiatif sendiri;

12. Mendorong peserta didik berfikir intuisi dan merumuskan hipotesis sendiri;

13. Memberikan keputusan yang bersifat intrinsik;

14. Situasi proses belajar menjadi lebih terangsang;

15. Proses belajar meliputi sesama aspeknya peserta didik menuju pada pembentukan manusia seutuhnya,

16. Meningkatkan tingkat penghargaan pada peserta didik.

17. Kemungkinan peserta didik belajar dengan memanfaatkan berbagai jenis sumber belajar.

18. Dapat mengembangkan bakat dan kecakapan individu.

\section{Kerangka Konseptual}

Kerangka konseptual ini menggambarkan hubungan antara variabel tindakan dan variabel harapan. Variabel tindakan yaitu mengoptimalkan penerapan pendekatan saintifik model discoveri learning, Sedangkan variabel harapan adalah meningkatkan motivasi dan hasil belajar.

\section{Hipotesis Tindakan}

"Jika penerapan Model discovery learning dilaksanakan secara optimal maka motivasi dan hasil belajar Tematik peserta didik kelas IV Semester Satu tahun pelajaran 2018/2019 dapat ditingkatkan".

\section{METODE PENELITIAN \\ Setting Penelitian}

Penelitian tindakan kelas (PTK) ini akan dilaksanakan di kelas IV SD Negeri 14 
Cakranegara Semester Satu tahun pelajaran 2018/2019, dengan jumlah peserta didik sebanyak 38 0rang.

\section{Faktor yang Diteliti}

1. Faktor Guru: yaitu dengan mengganti cara guru membuat Rencana Pelaksanaan Pembelajaran (RPP) dan pelaksanaannya dalam pembelajaran di kelas senyatanya dengan menerapkan pendekatan saintifik model discovery learning dalam upaya meningkatkan motivasi dan hasil belajar Tematik peserta didik Kelas IV SD Negeri 14 Cakranegara.

2. Faktor Peserta Didik: yaitu peningkatan motivasi dan hasil belajar yang terlihat pada perilaku peserta didik selama diskusi kelompok, yang berdampak pada peningkatan motivasi dan hasil belajar Tematik peserta didik Kelas IV Semester Satu Tahun pelajaran 2018/2019 di SD Negeri 14 Cakranegara.

\section{Rencana Tindakan}

Tindakan nyata yang dilakukan oleh guru selaku peneliti adalah dengan menggunakan siklus. Gambaran siklus dalam penelitian ini adalah sebagai berikut:

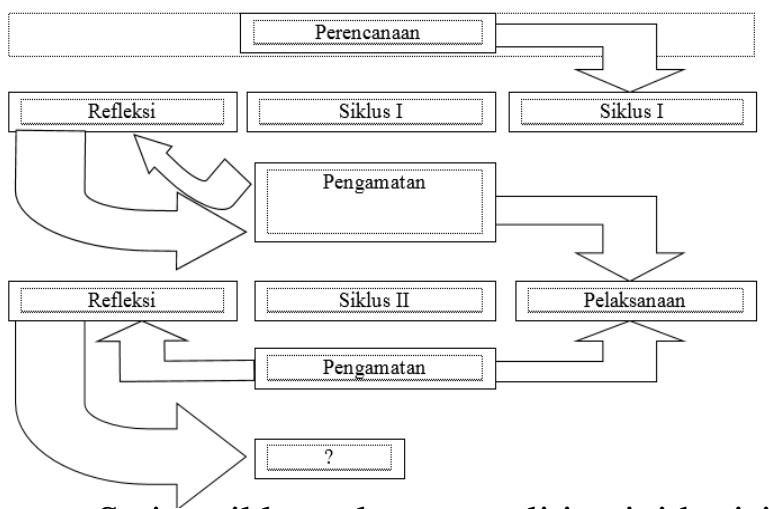

Setiap siklus selama penelitian ini berisi 4 (empat) tahapan yaitu: 1) Perencanaan (Planning), 2) Pelaksanaan (Action), 3) Observasi (Observation), dan 4) Refleksi (Reflection).

\section{SIKLUS I}

\section{Tahap Perencanaan (Planning)}

1. Menyusun Rencana Pelaksanaan Pembelajaran (RPP) dengan skenario sesuai dengan aturan main model pembelajaran saintifik model discovery learning

2. Menyiapkan sumber, bahan, dan semua alat yang digunakan dalam penelitian.
3. Menyusun/membuat lembar observasi guru dan lembar observasi peserta didik.

4. Menyusun alat evaluasi.

Tahap Pelaksanaan (Action)

1. Guru membagi peserta didik menjadi 8 (delapan) kelompok kecil, masing-masing kelompok beranggotakan 4-5 orang peserta didik.

2. Masing-masing kelompok diberikan tugas/soal untuk dipecahkan bersama dalam kelompok, selanjutnya guru berkeliling untuk membimbing kelompok utamanya yang mengalami kesulitan/permasalahan.

3. Masing-masing kelompok maju kedepan untuk mempresentasikan hasil kerja kelompok secara bergiliran.

4. Tes tertulis

\section{Tahap Observasi (Observation)}

1. Observasi guru : Dilakukan oleh pembimbing mata pelajaran Tematik observer sekaligus sebagai pembimbing guru dalam melaksanakan Penelitian Tindakan Kelas (PTK).

2. Observasi Peserta Didik : Dilaksanakan oleh guru mata pelajaran sekaligus sebagai peneliti dalam Penelitian Tindakan Kelas (PTK) pada kegiatan diskusi kelompok. Adapun aspek yang diamati meliputi sikap/karakter.

\section{Tahap Refleksi (Reflection)}

1. Renungan hasil perolehan data

2. Pengolahan dan analisa data hasil penelitian

3. Mencocokkan hasil analisa data dengan indikator keberhasilan

4. Rencana perbaikan dan tindak lanjut

\section{SIKLUS II}

Pada siklus ini semua kegiatan dan tahapan selama penelitian adalah sama, sifatnya mengulang dan memperbaiki terhadap tindakan yang masih memerlukan penyempurnaan dan pembenaran sebagaimana mestinya.

\section{Data dan Cara Pengambilannya. \\ Sumber Data}

Yang menjadi sumber data dalam penelitian tindakan kelas (PTK) ini adalah semua peserta didik kelas IV Semester Satu tahun pelajaran 2018/2019 di SD Negeri 14 Cakranegara dan peneliti. 


\section{Jenis Data}

- Jenis data yang berasal dari guru selaku peneliti

1). Data tentang Rencana Pelaksanaan Pembelajaran (RPP)

2). Data Pelaksanaan Pembelajaran

- Jenis data yang berasal dari peserta didik

1). Data kemajuan motivasi belajar

2). Data hasil diskusi kelompok

3). Data hasil belajar

\section{Cara Pengambilan data}

- Data kegiatan pembelajaran diambil dari RPP yang dibuat oleh guru dan lembar observasi pelaksanaan metode pembelajaran model discovery learning

- Data kemajuan motivasi belajar; diambil dari lembar observasi selama diskusi kelompok.

- Data kemajuan hasil belajar; diambil dari laporan individu hasil diskusi kelompok dan hasil tes tertulis yang dilaksanakan pada akhir proses pembelajaran

Indikator Keberhasilan dan Teknik analisa data

Teknik analisa data

Untuk menganalisis data akan dilakukan melalui analisis deskriptif kuantitatif melalui pendataan, analisis dan pembahasan terhadap data yang diperoleh dengan mencocokkan tingkat keoptimalan terhadap capaian indikator keberhasilan yang ada.

Indikator Keberhasilan

1. guru telah dinyatakan berhasil melaksanakan proses pembelajaran dengan pendekatan saintifik model discovery learning, bila telah mencapai skor rata-rata $\geq 4,00$ (kategori baik)

2. Motivasi belajar Tematik peserta didik kelas IV dinyatakan telah meningkat jika $85 \%$ dari jumlah peserta didik telah memperoleh skor rata-rata $\geq 4,0$ dan hasil belajar dinyatakan telah meningkat jika $85 \%$ dari jumlah peserta didik memperoleh nilai rata-rata $\geq 75,00$ (sesuai KKM).

\section{HASIL DAN PEMBAHASAN}

Pada tahapan ini yang telah dilakukan oleh guru selaku peneliti adalah; 1) menyusun RPP dengan skenario pembelajaran model discovery learning, 2) telah berhasil menyiapkan alat, sumber, bahan yang diperlukan dalam penelitian, 3) berhasil menyusun instrument observasi guru dan instrument observasi peserta didik, dan 4) menyusun alat evaluasi.

\section{Tahap Pelaksanaan}

1. Guru menyampaikan materi pelajaran dengan pendekatan saintifik dengan kegiatan mengamati dan menanya

2. Peserta didik dibagi menjadi 8 kelompok kecil yang anggotanya $4-5$ orang peserta didik secara heterogen

3. Peserta didik berdiskusi dengan model discovery learning dengan kegiatan pokoknya memecahkan persoalan/soalsoal yang menjadi tanggung jawabnya.

4. Selama peserta didik berdiskusi, guru berkeliling membimbing kelompok sekaligus melakukan observasi/pengamatan terhadap aspekaspek yang telah direncanakan.

5. Masing-masing kelompok secara bergiliran mempresentasikan di depan kelas yang diikuti oleh semua anggota kelompok.

6. Guru mengamati/mengobservasi ketrampilan peserta didik selama persentasi sesuai dengan aspek pengamatan ketrampilan yang telah di rencanakan.

7. Tes tertulis

\section{Tahap Observasi}

Observasi guru memperoleh skor ratarata sebesar 3,43, Observasi Peserta didik memperoleh skor rata-rata sebesar 3,23, dan hasil belajar dalam bentuk tes tertulis memperoleh nilai rata-rata sebesar 74,42

\section{Tahap Refleksi}

1. Renungan data hasil perolehan data pada siklus I

2. Pengolahan data hasil observasi guru, peserta didik dan tes tertulis.

3. Mencocokkan hasil yang ada dengan Indikator keberhasilan.

4. Merencanakan perbaikan terhadap jenis tindakan yang menyebabkan belum tuntas Indikator keberhasilan. Oleh karena Indikator keberhasilan belum terbukti maka penelitian dilanjutkan ke siklus II. 


\section{DESKRIPSI SIKLUS II}

Tahap Perencanaan

Pada tahapan ini jenis kegiatan yang dilakukan masih mengacu pada kegiatan siklus I, bedanya hanya terjadi perbaikan seperlunya yaitu: 1) penyusunan RPP dengan mengacu pada pendekatan saintifik model discovery learning dan diskusi kelompok dan penyempurnaan pada bagian skenario pembelajaran, 2) menyiapkan alat, sumber, bahan yang diperlukan dalam proses tindakan dikelas senyatanyan, 3) menyiapkan lembar observasi guru dan lembar observasi peserta didik sebagaimana pada siklus I, 4) menyiapkan alat evaluasi sebagaimana yang telah dibuat pada siklus I.

\section{Tahap Pelaksanaan}

Secara umum tahapan pelaksanaan proses pembelajaran pada siklus II ini masih mengacu pada pelaksanaan proses pembelajaran sebelumnya. Pemecahan yang dilakukan pada proses pembelajaran ini adalah: 1) pelaksanaan proses diskusi kelompok kecil lebih dioptimalkan, 2) pelaksanaan pembimbingan kelompok sekaligus observasi peserta didik lebih di efektifkan. Utamanya pengamatan peserta didik yang aktif, yang kurang aktif, peserta didik yang tidak aktif, dengan harapan proses analisa data lebih signifikan, 3) laporan hasil kerja kelompok yang dibuat secara individu yang dipresentasikan dikelas difokuskan, dan 4) pelaksanaan tes tertulis sebagai perwujudan dari peningkatan hasil belajar peserta didik lebih diperketat.

\section{Tahap Observasi}

Observasi guru memperoleh skor ratarata sebesar 4,63, Observasi Peserta didik memperoleh skor rata-rata sebesar 4,37, dan hasil belajar dalam bentuk tes tertulis memperoleh nilai rata-rata sebesar 89,61

\section{Tahap Refleksi}

1. Renungan atas perolehan data hasil observasi guru, observasi peserta didik, dan hasil tes tertulis sebagai wujud dari peningkatan motivasi dan hasil belajar peserta didik di kelas senyatanya.

2. Pengolahan data hasil observasi guru, observasi peserta didik, presentasi peserta didik dan tes tertulis
3. Mencocokkan perolehan data hasil tindakan dengan Indikator keberhasilan yang telah ditetapkan.

4. Guru memberikan hadiah/reward kepada semua peserta didik kelas IV atas keberhasilannya dalam upaya meningkatkan motivasi belajar yang berdampak terhadap perolehan hasil belajar sesuai dengan KKM yang telah ditetapkan.

\section{Pembahasan \\ Tahap Perencanaan}

Peneliti menyusun RPP dengan skenario penerapan pendekatan Saintifik model Discovery Learning, menyiapkan alat, sumber, bahan yang diperlukan dalam proses pembelajaran, menyiapkan instrument observasi guru maupun instrument observasi peserta didik. Ada kendala yang dihadapi selama persiapan alat dan bahan pembelajaran, tetapi setelah meminta petunjuk kepada pembimbing kendala yang dihadapi pun dapat diatasi dengan baik.

\section{Tahap Pelaksanaan}

a. Mengamati

- Guru menugaskan kepada peserta didik secara berkelompok untuk menggali informasi dari buku paket tentang materi pelajaran yang disajikan.

- Guru menjelaskan materi pelajaran dan memberikan contoh konkrit yang bisa dimengerti oleh peserta didik

\section{b. Menanya}

- Guru memberikan trik-trik kepada peserta didik tentang tata cara bertanya yang baik dan benar sesuai dengan materi pelajaran yang sedang disajikan.

- Peserta didik secara teratur bertanya tentang hal-hal yang belum dimengerti sesuai materi yang sedang dipelajari.

c. Mencoba (mengumpulkan data/informasi)

- Secara berkelompok peserta didik mendiskusikan masalah yang menjadi tanggung jawabnya.

- Melakukan eksperimen dalam kelompok terhaadap permasalahan yang sedang di diskusikan

- Mengumpulkan data yang berasal dari semua anggota kelompok 
d. Mengasosiasikan/mengolah informasi

- Semua anggota kelompok menjawab dan menelaah semua jawaban yang telah di diskusikan bersama

- Hasil jawaban di analisis bersama untuk bisa di paparkan di depan kelas pada saat menyampaikan informasi

- Kelompok membuat kesepakatan akhir dari hasil diskusi kelompok

e. Mengkomunikasikan

1. Guru kembali menyampaikan uraian materi pelajaran terkait dengan hasil kegiatan mengamati, menanya, mencoba, dan mengolah informasi.

2. Guru mempersilahkan kepada semua anggota kelompok untuk menginformaasikan hasil kerja kelompoknya.

3. Semua peserta didik secara berkelompok menanggapi setiap paparan dari kelompok lain

4. Peserta didik dengan bimbingan guru membuat kesimpulan bersama dari seluruh permasalahan/soal yang menjadi tanggung jawabnya.

5. Tes tertulis.

\section{Tahap Observasi}

Observasi guru memperoleh skor ratarata 3,43, sementara Indikator keberhasilan yang diharapkan $(\geq 4,0)$, hasil observasi peserta didik dalam upaya peningkatan motivasi dan hasil belajar Tematik peserta didik kelas IV Semester Satu tahun pelajaran 2018/2019 di SD Negeri 14 Cakranegara diperoleh skor rata-rata $(3,23)$. Dari hasil tes tertulis yang materinya hanya sekitar yang diajarkan pada saat itu juga, diperoleh nilai rata-rata $(74,42)$ kategori cukup.

\section{Tahap Refleksi}

Hasil analisa data peningkatan motivasi belajar pada siklus I ini $(3,23)$ sedangkan yang diminta dalam Indikator keberhasilan $(\geq$ $4,0)$, ini artinya belum berhasil.

Karena Indikator keberhasilan belum tercapai, penelitian tindakan kelas (PTK) dilanjutkan ke siklus II dengan harapan optimalisasi penerapan strategi pembelajaran dengan pendekatan saintifik model discovery learning dapat meningkatkan motivasi belajar Tematik peserta didik kelas IV Semester Satu tahun pelajaran 2018/2019 di SD Negeri 14 Cakranegara.

\section{SIKLUS II}

\section{Tahap Perencanaan}

Peneliti menyusun Rencana

Pelaksanaan Pembelajaran (RPP) dengan memperhatikan kesalahan-kesalahan pada siklus I. peneliti lebih memfokuskan tentang Rencana strategi jitu sehingga proses pembelajaran dengan pendekatan Saintifik model Discovery Learning dapat terelaisasi dengan baik, karenanya dalam penyusunan skenario benar-benar dirinci dari tiap aspek pada proses pembelajaran dengan model Discovery Learning.

Sebelum proses pembelajaran dilaksanakan, peneliti menyiapkan semua alat, bahan, dan segala sesuatunya sehingga dalam pelaksanaan proses pembelajaran berjalan sesuai dengan skenario yang telah direncanakan. Agar proses pembelajaran dapat teratasi maka peneliti juga menyiapkan lembar observasi guru dan lembar observasi peserta didik sebagai tolak ukur ketercapaian peningkatan motivasi dan hasil belajar Tematik peserta didik kelas IV SD Negeri 14 Cakranegara.

\section{Tahap Pelaksanaan}

Pada tahap pelaksanaan di siklus II ini pada dasarnya masih mengacu pada pelaksanaan siklus I, yaitu penerapan pendekatan Saintifik model Discovery Learning dan. Bedanya pada siklus ini lebih dioptimalkan.

\section{Tahap Observasi}

Pada siklus II ini hasil skor rata-rata $(4,63)$ sementara Indikator keberhasilan yang diharapkan $(\geq 4,0)$, Upaya meningkatkan motivasi belajar Tematik peserta didik kelas IV Semester Satu tahun pelajaran 2018/2019 di SD Negeri 14 Cakranegara diperoleh skor rata-rata $(4,37)$, sementara Indikator keberhasilan yang telah diharapkan adalah $(\geq$ $4,0)$, ini artinya perolehan skor rata-rata telah melampaui dari Indikator keberhasilan. Dampak nyata dari meningkatnya motivasi belajar adalah hasil belajar juga meningkat, dari data hasil perolehan nilai rata-rata tes tertulis adalah $(89,61)$ sementara pada siklus sebelumnya hanya $(74,42)$ berarti mengalami peningkatan (15.19). 


\section{Tahap Refleksi}

Hasil analisa data peningkatan motivasi dan hasil belajar peserta didik pada siklus II adalah $(4,37)$ dan $(89,61)$ sedangkan Indikator keberhasilan $(\geq 4,0)$ dan $\geq 75,00$. Ini artinya pada siklus II hasilnya telah melampaui Indikator keberhasilan yang telah di tetapkan.

Karena Indikator keberhasilan telah terbukti, maka tidak perlu ada upaya perbaikan dan penyempurnaan. Pendekatan Saintifik model Discovery Learning telah mampu meningkatkan motivasi dan hasil belajar peserta didik yang ditandai dengan tercapainya Indikator keberhasilan dan terjadinya peningkatan hasil belajar peserta didik. "Penelitian Tindakan Kelas (PTK) dihentikan pada siklus II dengan hasil memuaskan.”

\section{SIMPULAN DAN SARAN \\ Simpulan}

Data komulatif dari hasil penelitian tindakan kelas (PTK) dari siklus I ke Siklus II adalah sebagai berikut:

\begin{tabular}{|c|l|c|c|c|c|}
\hline No & \multicolumn{1}{|c|}{ Jenis Kegiatan } & $\begin{array}{c}\text { Indikator } \\
\text { keberhasilan }\end{array}$ & Siklus I & Siklus II & Keterangan \\
\hline 1. & Observasi Guru & $\geq 4,00$ & 3,43 & 4,63 & Meningkat \\
\hline 2. & Observasi Peserta didik & $\geq 4,00$ & 3,23 & 4,37 & Meningkat \\
\hline 3. & Tes tertulis & $\geq 75,00$ & 74,42 & 89,61 & Meningkat \\
\hline
\end{tabular}

Penerapan pendekatan Saintifik model Discovery Learning sangat efektif upaya untuk meningkatkan motivasi dan hasil belajar Tematik peserta didik kelas IV Semester Satu tahun pelajaran 2018/2019 di SD Negeri 14 Cakranegara. Fakta telah menunjukkan perolehan rata-rata skor motivasi belajar peserta didik pada siklus I ke siklus II sudah melampaui Indikator keberhasilan yang ditetapkan. Penelitian dinyatakan "berhasil" dan dihentikan pada siklus II.

\section{Saran-Saran}

Disarankan kepada guru sejawat untuk melaksanakan Penelitian Tindakan Kelas (PTK) dalam upaya untuk meningkatkan motivasi dan hasil belajar peserta didik sesuai dengan mata pelajaran masing-masing.

Disarankan kepada para semua peserta didik kelas IV SD Negeri 14 Cakranegara untuk membiasakan belajar dengan pendekatan yang kontekstual utamanya strategi yang mampu membangkitkan motivasi belajar peserta didik yang dampaknya hasil belajar dapat ditingkatkan seperti yang diharapkan.

\section{DAFTAR PUSTAKA}

Anonim, 2018, dalam http://dadangjsn.blogspot.com/2014/0 6/pengertiandefinisi-pendekatansaintifik.html, Tanggal 28 Juli 2018, Pukul 15.32 Wita

Arikunto, s. 2009, Penelitian Tindakan Kelas, Jakarta : Bumi Aksara.

Harun Rasyid dan Mansur, 2008, Penilaian Hasil Belajar, Bandung : CV Wacana Prima.

Lukmanul A, 2008, Perencanaan Pembelajaran, Bandung : CV Wacana Prima.

Mukhtar, 2003, Prosedur Penilaian, Jakarta : Rineka Cipta.

Nurhadi, 2003, Yasin ,B dan Sendule.A, 2003, Kontekstual dan Penerapannya dalam KBK, Malang : Unitipetas Negeri Malang.

Robert E Slavin, 2010, Cooperative Learning Teori, riset dan Praktik, Bandung : Nusa Media.

Sardiman, 2007, Indikator Dan Motivasi Belajar Mengajar, Jakarta : Raja Grafindo Perkasa.

Supriono, 2009, Cooperative Learning Teori dan Aplikasi PAIKEM, Yogyakarta : Pustaka Pelajar.

Permen 81A Tahun 2013 Tentang Implementasi Kurikulum 2013 